\title{
Analysis of Factors Affecting Patient Satisfaction JKN Non PBI at Primary Health Care in East Jakarta District 2016
}

\author{
*Cahya Arbitera, **Amal Chalik Sjaaf, **Wahyu Sulistiadi \\ * Faculty of Public Health Univesitas Indonesia \\ ** Department Health Administration and Policy, Faculty of Public Health Universitas Indonesia \\ Email: chy.arbitera83ui@gmail.com
}

\begin{abstract}
Health development in the period 2015-2019 is Indonesia Sehat program with the goal to improve the health and nutritional status of the community through health and community empowerment efforts which are supported with financial protection and health care equity. Social Health Security Agency (BPJS) as JKN organizers estimate in 2015 is a deficit of more than 6 trillion rupiahs. In 2016, the deficit is estimated to be 11 trillion rupiahs. This study used a crosssectional study design. The population in this study were outpatients at the sub-district Kramat Jati and Pasar Rebo primary health care with the total number of 800 people and studied sample of 100 people. Patient satisfaction in this study has mean score of 43,06. Education variable; job and services are not significantly affects patient satisfaction JKN Non PBI at East Jakarta district primary heallth care. In conclusion, dimension of punctuality; convenience in obtaining services and ease in obtaining services most influence on patient satisfaction JKN Non PBI in East Jakarta district primary health care with the $\mathrm{p}$ value $=0,000<0,05$. In addition, politeness and friendliness within the service still have big influence on patient satisfaction bicause it is important factors on patient satisfaction. Therefore, the author gives some recommendations to appropriate and thorough improvement added with upgrading to the punctuality of service, conducting a survey of patient satisfaction by BPJS and primary health care, disseminating the research results regarding the effect of service quality on patient satisfaction level, further and in-depth research needs to be done related to the effect on service quality dimension to JKN patient satisfaction level in all primary health care included in East Jakarta district, especially at primary health care which has never been conducted with survey and research on JKN patient satisfaction level.
\end{abstract}

Keywords: patient satisfaction, JKN, non PBI, primary health care

\begin{abstract}
Abstrak. Pembangunan kesehatan pada periode 2015-2019 adalah Program Indonesia Sehat dengan sasaran meningkatkan derajat kesehatan dan status gizi masyarakat melalui melalui upaya kesehatan dan pemberdayaan masyarakat yang didukung dengan perlindungan finansial dan pemeratan pelayanan kesehatan. Badan Penyelenggara Jaminan Sosial (BPJS) Kesehatan sebagai penyelenggara JKN memperkirakan pada 2015 akan mengalami defisit lebih dari 6 triliun rupiah. Pada 2016, defisit diperkirakan menjadi 11 triliun rupiah. Penelitian ini menggunakan desain studi cross-sectional. Populasi dalam penelitian ini adalah pasien rawat jalan di Puskesmas Kecamatan Kramat Jati dan Pasar Rebo yang berjumlah 800 orang dan sampel yang diteliti sebesar 100 orang. Hasil kepuasan pasien dalam penelitian ini memiliki rata-rata skor 43,06. Variabel jenis kelamin dan pekerjaan tidak berpengaruh signifikan terhadap kepuasan pasien JKN Non PBI pada Puskesmas Kecamatan Jakarta Timur. Kesimpulannya variabel yang paling berpengaruh terhadap kepuasan pasien JKN Non PBI Pada Puskesmas Kecamatan Jakarta Timur adalah ketepatan waktu;kemudahan mendapat pelayanan dan kenyamanan mendapatkan pelayanan dengan $p$ value $=0,000<0,05$. Kesopanan dan keramahan petugas serta pelayanan dinyatakan tetap berpengaruh terhadap kepuasan dikarenakan dianggap merupakan faktor-faktor yang penting dalam kepuasan pelayanan. Peneliti memberikan beberapa rekomendasi untuk melakukan perbaikan dan peningkatan pada pelayanan, melakukan survey kepuasan pasien oleh BPJS maupun Puskesmas, penyampaian hasil-hasil penelitian tentang pengaruh kualitas pelayanan terhadap tingkat kepuasan pasien, mengiadakan penelitian lebih lanjut dan mendalam terkait pengaruh pada dimensi kualitas pelayanan terhadap tingkat kepuasan pasien JKN di seluruh Puskesmas yang termasuk dalam wilayah Jakarta Timur khususnya pada Puskesmas yang belum pernah dilakukan survey dan penelitian tentang tingkat kepuasan pasien JKN.
\end{abstract}

Kata kunci: kepuasan, JKN, non PBI, puskesmas

\section{INTRODUCTION}

The purpose of the Indonesian nation as stated in the Preamble to the 1945 Constitution paragraph 4 is to protect the entire nation of Indonesia and the entire blood of Indonesia and to promote the general welfare and the intellectual life of the nation. To achieve these objectives, national development programs are implemented in a sustainable, planned and directed manner. Health development is an integral and essential 
part of a national development program. One of the six main targets of the Medium-Term National Development Plan (RPJMN) 2015-2019 is the increased coverage of universal health services through the Healthy Inodonesia Card (KIS) and the quality of the management of the National Social Security System (SJSN) Health, in which one of the health management arranged in the national health system within the healthcare subsystem.

The success of the National Health Insurance (JKN) development has been implemented since January 1, 2014 based on the mandate of the 1945 Constitution and the National Law no.40 Year 2004 on the National Social Security System (SJSN) for the achievement of universal health insurance. Aspect of health service is aspect which need to be considered since the health service is the second key success in the JKN implementation after aspects of regulation, membership, benefits, financial and institutional (DJSN, 2012). The implementation of health services in the JKN era covers all health facilities in cooperation with the Social Security Administering Body (BPJS)Health in the form of First-Level Health Facility (FKTP) and Advanced-Level Health Facility (FKRTL), where FKTP is in the form of primary health care (Puskesmas) or equivalent; doctor, dental practice or equivalent; and D-class Primary hospitals or equivalent; which should provide comprehensive health services (Ministry of Health, 2013). As an implementation form of the National Law No. 40 Year 2004 on SJSN, then formed later National Law No. 24 Year 2011 on Social Security Administering Body (BPJS).

Primary health care (Puskesmas) are obliged to implement every policy stipulated by the government, one of which is the policy of the National Health Insurance program implementation. In the implementation of the National Health Insurance program, in accordance with the Minister of Health Regulation No. 71 Year 2013 about Health Services on National Health Insurance, mentioned that the primary health care serves as one of the first-level health facilities in the provision of health services. The National Health Insurance (JKN) is a part of the National Social Security System (SJSN) which is organized by using mandatory social health insurance mechanism based on National Law No. 40 Year 2004 on SJSN, with the aim of fulfilling feasible basic needs of public health which granted to every person who has paid contributions or paid by the Government (Ministry of Health, 2012).

The number of participants BPJS Health which has been recorded until the month of March 2016 nationally as many as 163.327 .183 people (Official Website BPJS Health Year 2016). The biggest composition of participants is non-PBI and independent participants i.e. wage workers and non-wage workers. Therefore, nonPBI and independent participants are highly prospective participants in the JKN program; so, they should get maximum attention and effort to achieve the high satisfaction of health service. The number of participants of BPJS Health registered at East Jakarta Branch Office were 886,382 people $(37.2 \%)$ for wage workers (PPU); 245,134 people $(10.3 \%)$ for independent participants; 116,420 people $(4.9 \%)$ for non-workers; 324,801 people $(13.6 \%)$ for Beneficiaries of Contribution (PBI); and 809,664 people (34.0\%) of guaranteed by Jamkesda. (Presentation Data of BPJS Health of East Jakarta Branch Office in Pre Apindo of East Jakarta).

The number of patient visits at Kramat Jati District primary health care was decreased in 2015 , based on the 2014 December data of 30,309 people to 26,825 people in 2015 in the same month. This is probably caused by the decrease of patient satisfaction on the quality of service at the primary health care (Data of Kramat Jati Sub-district primary health care, East Jakarta Area). For the number of patient visits at Pasar Rebo Sub-district primary health care recorded in May 2015 amounted to 5,527 people and increased significantly in May of 2016 to 7,888 people.

Based on the recording number of JKN patient visit, which is BPJS Non-PBI at primary health care of Pasar Rebo Sub-district keeps increasing from 2014 until 2016 which is equal to 16,388 people in April 2014. In the month of April, recorded that there are 28,531 people in 2015 and 30.283 people in 2016 (Data of Pasar Rebo Sub-district primary health care of East Jakarta Region). This shows the increasing trust of patients in general and patients of BPJS Non-PBI especially to Pasar Rebo primary health care.

Data collection and recording which has been done by BPJS Health until 2015 are including capitation data, type of disease, age of participant and total visit of JKN patient as a whole. The BPJS Health as the organizer of JKN estimates that JKN will have a deficit of more than $\mathrm{Rp} 6$ trillion in 2015; furthermore, the deficit is expected to increase until Rp11 trillion in 2016. So far, things which has been done is a survey on the satisfaction level analysis of service received by JKN patients at the primary health care based on samples of the existing branches. However, survey regarding patient satisfaction level of Non-PBI JKN at Kramat Jati and Pasar Rebo primary health care, which is included in BPJS Health of East Jakarta branch, has not been conducted yet.

\section{METHOD}

This research uses cross sectional design which aims to get an overview of factors that affect patient satisfaction JKN Non PBI at primary health care in East Jakarta district. The cross-sectional design intends to obtain: a) a description of the respondents' demographic characteristics; b) description of factors that affect patient satisfaction of JKN Non PBI; c) description of patient satisfaction of JKN Non-PBI; d) information on the influence of characteristic factors; and e) dimensions of public service quality with patient satisfaction of 


\section{JKN Non-PBI.}

This research was conducted at the primary health care of Kramat Jati and Pasar Rebo Subdistrict. This study was also conducted within one month of June 2016. The study population of this study were all patients of JKN at Kramat Jati and Pasar Rebo Subdistrict primary health care with a sample of 100 people. This study used a structured and closed questionnaire in the measurement of independent and dependent variables.

The analysis done in this research is univariate analysis presents data in the form of proportion for the data which is categorical and the mean value for data that is numerical. Bivariate analysis with Anova and NonParametric test aims to examine the difference of proportion between independent variable (age, sex, education, occupation, and satisfaction from public service) and dependent (patient satisfaction of JKN Non-PBI).

\section{RESULT AND DISSCUSSION}

\section{Characteristics of Respondents}

The demographic characteristics of respondents in the form of categorical data are outlined by age, gender, education and occupation. Meanwhile, the dimension of public service quality in the form of numerical data is the punctuality, politeness and friendliness, responsibility, ease of service and convenience to get service. The number of respondents aged in the category of elderly is more that 89 people and age in the category of adolescents and adults as many as 11 respondents. Male respondents were fewer than female respondents is 39 people and 61 female respondents. Respondents with less education or complete 9-year compulsory education as many as 60 people and the number of respondents who are educated more than 9year compulsory education as many as 40 people.

Most of the respondents are in the category of work which is 61 people and who entered in the category not working is 39 people. Almost half of the respondent's parents work as entrepreneurs/sellers and farmers $(51.90 \%)$ (Table 5.1). The average distance of the respondent's house to the school is 527.6 meters with the closest distance is 9 meters and the farthest distance is 2,000 meters. The length of the journey traveled an average of 7.4 minutes with the fastest time of 1 minute and the longest time of 20 minutes. Rata-rata lama responden berada di sekolah adalah 5,5 jam dalam sehari dan rata-rata lama responden berada di sekolah adalah 17,2 jam dalam sehari. The average length of respondents in school is 5.5 hours a day and the average length of respondents in school is 17.2 hours a day. Meanwhile, the average distance of the respondent's house to the highway is 1,804 meters with the closest distance is 2 meters and the furthest distance is 50,000 meters.

\begin{tabular}{|c|c|c|}
\hline Characteristics & Total & Percentage \\
\hline \multicolumn{3}{|l|}{ Age } \\
\hline Adolescence and Adult & 11 & 11,0 \\
\hline \multicolumn{3}{|l|}{ Sex } \\
\hline Male & 39 & 39,0 \\
\hline Female & 61 & 61,0 \\
\hline \multicolumn{3}{|l|}{ Education } \\
\hline $\begin{array}{l}\leq 9 \text {-year compulsory } \\
\text { education }\end{array}$ & 60 & 60,0 \\
\hline $\begin{array}{l}>9 \text {-year compulsory } \\
\text { education }\end{array}$ & 40 & 40,0 \\
\hline \multicolumn{3}{|l|}{ Occupation } \\
\hline $\begin{array}{l}\text { Employees (public and } \\
\text { private) }\end{array}$ & 61 & 61,0 \\
\hline Not working & 39 & 39,0 \\
\hline
\end{tabular}

Table 2. Distribution of respondents' assessment on the dimension of public service quality at primary health care sub-district of East Jakarta in 2016

\begin{tabular}{|l|c|c|c|c|}
\hline \multicolumn{1}{|c|}{ Variable } & Mean & SD & $\begin{array}{c}\text { Minimun- } \\
\text { Maximum }\end{array}$ & $\mathbf{9 5 \% ~ C I}$ \\
\hline Punctuality & 7,26 & 1,346 & $4-8$ & $6,99-7,33$ \\
\hline $\begin{array}{l}\text { Politeness and } \\
\text { friendliness }\end{array}$ & 7,51 & 1,227 & $4-8$ & $7,27-7,75$ \\
\hline Responsibility & 5,92 & 0,367 & $3-6$ & $5,85-5,99$ \\
\hline $\begin{array}{l}\text { Ease in obtaining } \\
\text { services (location, } \\
\text { transportation, } \\
\text { ease to have } \\
\text { registration and } \\
\text { information)/ } \\
\text { LTPI }\end{array}$ & 7,84 & 0,420 & $6-8$ & $7,76-7,92$ \\
\hline $\begin{array}{l}\text { Convenience in } \\
\text { obtaining services }\end{array}$ & 5,31 & 1,061 & $3-6$ & $5,10-5,52$ \\
\hline $\begin{array}{l}\text { Service by } \\
\text { officers }\end{array}$ & 7,32 & 1,39 & $4-8$ & $7,04-7,60$ \\
\hline $\begin{array}{l}\text { Patient } \\
\text { satisfaction } \\
\text { (score) }\end{array}$ & 43,06 & 1,355 & $38-44$ & $\begin{array}{l}42,79- \\
43,33\end{array}$ \\
\hline
\end{tabular}

\section{Distribution of Punctuality assessment}

The measurement results show that the average value of punctuality is 7.26 with a standard deviation of 1.346. The minimum value is 4 and maximum 8 . From the interval estimation result, it could be concluded that $95 \%$ is believed that the average of punctuality is between 6.99-7,33.

\section{Distribution of Politeness and Hospitality assessment}

The measurement results show that the average value of punctuality is 7.51 with the standard deviation of 1.227. The minimum value is 4 and maximum 8 . From the interval estimation result, it could be concluded that $95 \%$ is believed that the average of punctuality is between 7,27-7,75.

\section{Distribution of Responsibility assessment}

The measurement results show that the average value of responsibility is 5.92 with the standard deviation of 0.367 . The minimum value is 3 and maximum 6 . From the interval estimation result, it could be concluded that 
$95 \%$ is believed that the average of responsibility is between 5.85-5.99.

\section{Distribution of Ease in Obtaining Services assessment}

The measurement results show that the average value of ease in obtaining the services is 7.84 with the standard deviation of 0.420 . The minimum value is 6 and a maximum of 8 . From the interval estimation result, it could be concluded that $95 \%$ is believed that the average of ease in obtaining services is between 7,767,92 .

\section{Distribution of Convenience in Obtaining Services assessment}

The measurement results show that the average time value of convenience in obtaining services is 5.31 with a standard deviation of 1.061 . The minimum value is 3 and maximum 6 . From the interval estimation result, it could be concluded that $95 \%$ is believed that the average of convenience in obtaining service is between 5.10-5.52.

\section{Distribution of Service assessment}

The measurement results show that the average value of service is 7.32 with a standard deviation of 1.39 . The minimum value is 4 and maximum 8 . From the interval estimation result, it could be concluded that $95 \%$ is believed that the average of service is between 7,047,60 .

\section{Distribution of Patients Satisfaction JKN Non PBI}

The measurement results show that the average value of patient satisfaction is 43.06 with a standard deviation of 1.355. The minimum value is 38 and a maximum of 44 . From the interval estimation results, it could be concluded that $95 \%$ is believed that the average of patient satisfaction is between 42.79 to 43.33 .

\section{Relationship between the characteristics of respondents to patients satisfaction JKN Non-PBI}

From result of analysis, shows no significant relation between age to patient satisfaction which is the $p$ value $=0,533>0,05$. For gender variable, there was no significant correlation to patient satisfaction with the $p$ value $=0,191>0,05$. Then the educational variable is known that there is no significant relationship to satisfaction because the $\mathrm{p}$ value $=0.086>0.05$. While in the ocupation variable also there is no significant relation to satisfaction with the $p$ value $=0,441>0,05$.

Table 3. Influence between characteristics to patient satisfaction

\begin{tabular}{lc}
\hline \multicolumn{1}{c}{ Year } & P Value \\
\hline Age & 0,436 \\
Sex & 0,441 \\
Education & 0,73 \\
Occupation & 0,441 \\
\hline
\end{tabular}

Relation of service quality dimension to patient satisfaction of Non PBI JKN

From result of analysis, shows there is no significant relation between time service accuracy to patient satisfaction that is $p$ value $=0,57>0,05$ with correlation value $(r)$. For variable officer's politeness and friendliness, there is also no significant relation to patient satisfaction with the $p$ value $=0,955>0,05$ with correlation value $(\mathrm{r})$ that is 0,006 . On variable officer's responsibility, no significant relation to patient satisfaction because the $p$ value $=0,055>0,05$ with 0,192 as correlation value (r). Then on the variable ease of service, there is a significant relationship to patient satisfaction with the $p$ value $=0,000<0.05$ with the value of correlation ( $r$ ) is 0.408 . While convenience in obtaining service variable, there is significant relation to patient satisfaction because $p$ value $=$ $0,000<0,05$ with correlation value (r) that is 0,472 . Service variable also have significant relation to patient satisfaction with $p$ value $=0,000<0,05$ with correlation value (r) that is 0,038 .

\begin{tabular}{|c|c|c|c|}
\hline Variable & Correlation (r) & P value & $\mathbf{N}$ \\
\hline Punctuality & 0,191 & 0,57 & 100 \\
\hline Politeness and friendliness & 0,006 & 0,955 & 100 \\
\hline Responsibility & 0,192 & 0,055 & 100 \\
\hline Ease in obtaining the service & 0,408 & 0,000 & 100 \\
\hline $\begin{array}{l}\text { Convenience in obtaining the } \\
\text { service }\end{array}$ & 0,472 & 0,000 & 100 \\
\hline Service & 0,038 & 0,000 & 100 \\
\hline
\end{tabular}

\section{Multivariate Analysis}

In multivariate analysis, this study used Multiple Linear Regression method. There are four major variables, which are three independent variables, namely the characteristics of respondents, the dimensions of service quality and the service variables. For the dependent variable is patient satisfaction. The result on the variable used is Numerical.

\begin{tabular}{|c|c|c|c|c|c|c|}
\hline \multicolumn{7}{|c|}{ Coefficients $^{a}$} \\
\hline & & \multicolumn{2}{|c|}{$\begin{array}{c}\text { Unstandardized } \\
\text { Coefficients }\end{array}$} & \multirow{2}{*}{$\begin{array}{c}\begin{array}{c}\text { Standard } \\
\text { ized } \\
\text { Coefficie } \\
\text { nts }\end{array} \\
\text { Beta } \\
\end{array}$} & \multirow[b]{2}{*}{$\mathrm{t}$} & \multirow[b]{2}{*}{ Sig. } \\
\hline \multicolumn{2}{|c|}{ Model } & B & $\begin{array}{l}\text { Std. } \\
\text { Error }\end{array}$ & & & \\
\hline & (Constant) & 23.510 & 2.404 & & 9.781 & .000 \\
\hline & Kelamin & -.263 & .202 & -.095 & -1.305 & 195 \\
\hline & Pendidikan & -.572 & .193 & -.208 & -2.956 & .004 \\
\hline & Pekerjaan & .190 & .205 & .069 & .924 & .358 \\
\hline & TW & .519 & .114 & .515 & 4.530 & .000 \\
\hline & S & -.243 & .138 & -.220 & -1.761 & .082 \\
\hline & TJ & .797 & .265 & .216 & 3.013 & .003 \\
\hline & $\mathrm{N}$ & .713 & .086 & .558 & 8.293 & .000 \\
\hline & YAN & -.127 & .119 & -.131 & -1.070 & .288 \\
\hline & LTPI & 1.403 & .213 & .435 & 6.583 & .000 \\
\hline 2 & (Constant) & 23.669 & 2.396 & & 9.880 & .000 \\
\hline & Kelamin & -.183 & .182 & -.066 & -1.006 & .317 \\
\hline & Pendidikan & -.541 & .190 & -.197 & -2.841 & .006 \\
\hline
\end{tabular}




\begin{tabular}{|c|c|c|c|c|c|c|}
\hline \multicolumn{2}{|r|}{ TW } & .515 & .114 & .511 & 4.503 & .000 \\
\hline & $S$ & -.236 & .138 & -.214 & -1.713 & .090 \\
\hline & TJ & .812 & .264 & .220 & 3.075 & .003 \\
\hline & $\mathrm{N}$ & .715 & .086 & .560 & 8.335 & .000 \\
\hline & YAN & -.137 & .118 & -.141 & -1.156 & .251 \\
\hline & LTPI & 1.388 & .212 & .430 & 6.535 & .000 \\
\hline 3 & (Constant) & 23.389 & 2.380 & & 9.829 & .000 \\
\hline & Pendidikan & -.543 & .190 & -.197 & -2.853 & .005 \\
\hline & TW & .524 & .114 & .521 & 4.599 & .000 \\
\hline & S & -.241 & .138 & -.219 & -1.752 & .083 \\
\hline & TJ & .787 & .263 & .213 & 2.995 & .004 \\
\hline & $\mathrm{N}$ & .721 & .086 & .565 & 8.428 & .000 \\
\hline & YAN & -.143 & .118 & -.146 & -1.204 & .232 \\
\hline & LTPI & 1.402 & .212 & .434 & 6.617 & .000 \\
\hline
\end{tabular}

In the first model, known that occupation variable has the highest value of $p$ value which is $p=$ 0.358 , then to continue on subsequent or second modeling, the occupatoin variables should be taken out. Seen in the second model after the occupation is taken out, then check the changes which exist in $\mathrm{R}$ Square and Coef $\mathrm{B}$ on each variable; in the second model, it is known that $R$ Squre does not change much similar to Coef $\mathrm{B}$ on each variable nothing changes more than $10 \%$ ). For subsequent modeling the gender variable with $p$ value $(p=317)$ is issued, the result is that $R$ Square does not change much that is followed by Coef $B$, each variable is not changed more than $10 \%$. Although politeness, hospitality and service have $p$ value $>0,05$; but they were not excluded from model because politeness, hospitality and service are considered as variable or factor which is also important and has big influence to patient satisfaction. With no exclusion of politeness, hospitality and service of the model; then the modeling is complete.

\section{CONCLUSION}

From the various results of data analysis and discussion of the findings in the study, it could be made the following conclusions:

1 Non-PBI patient satisfaction at primary health care in East Jakarta district has average score of 43,06 , with standard deviation value is 1,355 , minimum-maximum range value of $38-44$.

2 There is a significant correlation between the quality dimension being studied is the convenience in obtaining the service, the service and the ease in obtaining the service (location, transportation, registration, and information/LTPI) with the satisfaction of the
Non PBI patients at the East Jakarta District primary health care.

3 There is no significant relationship between the characteristics of the respondents; punctuality; politeness and friendliness; and responsibility of the officer to the satisfaction of JKN Non PBI patient at the East Jakarta District primary health care.

4 In conclusion, the most influential variable on satisfaction of JKN Non PBI patient at the East Jakarta District primary health care is punctuality; ease and convenience in obtaining service. Politeness and hospitality of officers and service still have an effect on patient satisfaction because they are considered as important factors in service satisfaction.

5 The sex and job variables did not significantly affect the satisfaction of the non-PBI JKN patients at the East Jakarta District primary health care.

6 Non-PBI patient satisfaction in the primary health care studied is known to be a good average value because it is close to the maximum value.

This study found that there is a significant influence on some dimensions of service quality which is puntuality; politeness and friendliness; the responsibilities of officers; the convenience in obtaining services; services; and ease in obtaining service. Therefore, the author gives some recommendations:

1. Appropriate and thorough improvement added with upgrading to the punctuality of service, hospitality and politeness of medical and nonmedical staff, officer responsibilities, convenience of service, service at all stages and ease in obtaining services at primary health care studies by special evaluation program to service which could see in terms of quality and quantity. This evaluation is done within a certain time, so that the quality of service could be maintained.

2. Conducting a survey or recording of patient satisfaction by BPJS and primary health care to the services provided, especially at the primary health care which has never been conducted the survey. For primary health care which has been done recording satisfaction, then the next step is to increase the satisfaction level. This program or activity should be carried out regularly and periodically.

3. Disseminating the research results regarding the effect of service quality on patient satisfaction level to the community, local government and primary health care under study; with the expectation of government and primary health care 
could improve the quality of good health service.

4. Further and in-depth research needs to be done related to the effect on service quality dimension to JKN patient satisfaction level in all primary health care included in East Jakarta district, especially at primary health care which has never been conducted with survey and research on JKN patient satisfaction level.

\section{REFERENCES}

Aditi, Naidu. (2008). Factors Affecting Patient Satisfaction and Healthcare Quality, India : IJHCQA

Aditya. (2011). Instalasi Rawat jalan. Tersedia di: http://www.geacities.com/Instalasi Rawat jalan /tipodua.html. [diakses 20 Mei 2016]

Alwi, Mujahit, Hasibuan. (2008). "Pengaruh Pelayanan Tenaga Kesehatan, Sarana dan Prasarana Pusekesmas, Serta Tarif Terhadap Permintaan Masyarakat Dalam Pelayanan Kesehatan Di Puskesmas Kota RantauPrapat, Tesis

Asep, Saefullah. (2015). “ Hubungan Kepuasan Dengan Loyalitas Pelanggan Pada Peserta BPJS Bukan Penerima Bantuan Iuran (Non PBI) Di Unit Rawat Jalan Puskesmas Kota serang

Azrul, A. (1996). Menuju Pelayanan Kesehatan Yang Bermutu. Yayasan Penerbit Ikatan Dokter Indonesia. Jakarta

Azwar, Azrul. (1996). Pengantar Administrasi Kesehatan. Jakarta : Sinar Harapan

Citra. (2012). Pengaruh Mutu Pelayanan Terhadap Kepuasan Pasien Rawat Inap RSU. Bunda Thamrin Medan Tahun 2012.

Edwin, Rusli. (2006). "Analisis Hubungan Antara Tingkat Kepuasan Dengan Keinginan Pasien Kembali Memanfaatkan Pelayanan Rawat Jalan Di Puskesmas Bukit Kemuning Kecamatan Bukit Kemuning Kabupaten Lampung Utara, Tesis

Gazpersz, V., 2005. Total Quality Management. Jakarta: PT Gramedia Pustaka Utama.

Imbalo, P. (2007). Jaminan Mutu Layanan Kesehatan: Dasar-Dasar Pengertian dan Penerapan. Jakarta: Penerbit Buku Kedokteran EGC

Jarot, Agus kasryanto. (2016). “ Analisis Faktor Yang Mempengaruhi Kepuasan Pasien Rawat Inap Peserta BPJS Non Penerima Bantuan Iuran Di Puskesmas Kabupaten Donggala, Tesis.

Kepmenpan No. 63 Tahun 2003 tentang Pedoman Umum Penyelenggaraan Pelayanan Publik

Kepmenpan. Nomor: 63/KEP/M.PAN/7/2003 Tentang Pedoman Umum Penyelenggaraan Pelayanan Publik.

Kepmenpan. Nomor: KEP/25/M.pan/2/2004 Tentang Pedoman Umum Penyusunan Indeks Kepuasan Masyarakat Unit Pelayanan Instansi Pemerintah

Ketut, Gunawan. (2011). "Kualitas Layanan Dan Loyalitas Pasien”. Studi pada Rumah Sakit Umum Swasta di Kota Singaraja-Bali, Jurnal Manajemen Kewirausahaan, Vol 13, No 1, Hal 32-39

Mardalis, Ahmad. (2015). Meraih Loyalitas Pelanggan. Jakarta : Balai Pustaka

Parasuraman, A., V. A. Zeithaml, dan L.L. Berry, 1998, SERVQUAL: A Multiple-Item Scale for Measuring Consumer Perceptions of Service Quality, Journal of Retailing, Vol. 64, No. 1. (http://mukhlidah.multiply.com/journal/item/63/).

Pohan, Imbalo S. (2006). Jaminan Mutu Layanan Kesehatan : Dasardasar Pengertian dan Penerapan. Jakarta : Kedokteran EGC.

Reflita. (2010). Faktor Yang Berhubungan Dengan Tingkat Kepuasan Pasien Terhadap Pelayanan Teknik Riset Pemasaran dan Ramalan Penjualan. Jakarta: PT. Rineka Cipta

Sudarsono, (2010). Konsep dan Penerapan Metodologi Penelitian Ilmu Keperawatan. Jakarta : Salemba Medika.

Suharmadji. (2003). "Analisis Tingkat Kepuasan Pasien Rawat Jalan Umum Puskesmas Di Kota Pekanbaru, Tesis

Supranto. (1997). Pengukuran Tingkat Kepuasan Pelanggan, Jakarta : Rineka Cipta

Tjiptono, F. (2006). Prinsip Total Quality Service (TQS), Yogyakarta : Andi Offset

Tjiptono, Gregorious. (2005). Service, Quality \& and Satisfaction. Yogyakarta : Penerbit Andi.
Ulfa, Royanah. (2016). "Analisis Tingkat Kepuasan Pasien Peserta Jaminan kesehatanAnalisis Tingkat Kepuasan Pasien Peserta Jaminan Kesehatan Nasional Bukan Penerima Bantuan Iuran (Non PBI) Di Puskesmas Halmahera Semarang Tahun 2015, Tesis

Wijani. (2009). Analisa Faktor Penentu Tingkat Kepuasan Pasien di RS Muhamaddiyah Bantur.

Wijono, Djoko, (2008). Waktu Pemeriksaan. http://www.Rancangan Sistem Informasi Pelayanan Medis Poliklinik .com/Waktu Pemeriksaan $/ \mathrm{htm}$. Diakses Tanggal 7 Januari 2012 Jam 11 pm.

Wijono, Djoko. (2008). Manajemen Mutu Rumah Sakit dan Kepuasan Pasien-pasien dan Praktik. Surabaya : CV Duta Prima Airlangga. 